\title{
FACTORS ASSOCIATED WITH QUALITY OF HEALTH SERVICES AND THE CONTEXTUAL EFFECT OF COMMUNITY HEALTH CENTER
}

\author{
Lukman Aryoseto'), Didik Tamtomo'), Bhisma Murti1) \\ 1)Masters Program in Public Health, Universitas Sebelas Maret \\ 2)Faculty of Medicine, Universitas Sebelas Maret
}

\begin{abstract}
Background: The quality of the employees' workplace environment impacts on their motivation level and hence performance. When employees have the desire, physically and emotionally to work, then their performance shall be increased. Work performance in turn affects the quality of health service. This study aimed to determine factors associated with quality of health service at Puskesmas (community health center) taking account of the contextual effect of Puskesmas as the workplace.

Subjects and Method: This was a cross sectional study conducted at Puskesmas Surakarta and Karanganyar, Central Java, from June to July 2018. A total of 25 Puskesmas was selected for this study. A sample of 225 patients was selected for this study. The dependent variable was quality of health service. The independent variables were patient income, health insurance status, educational status, work motivation of the doctor, work satisfaction of the doctor, experience of the doctor, and accreditation of Puskesmas. The data were collected by questionnaire and analyzed by a multilevel logistic regression.

Results: The quality of health service in Puskesmas increased with patient income $(b=0.39 ; 95 \% \mathrm{CI}=0.19$ to $0.59 ; \mathrm{p}<0.001)$, health insurance status $(\mathrm{b}=0.39 ; 95 \%$ $\mathrm{CI}=0.22$ to $0.64 ; \mathrm{p}<0.001)$, educational status $(\mathrm{b}=0.26 ; 95 \% \mathrm{CI}=0.15$ to 0.36 ; $\mathrm{p}<0.001)$, work satisfaction of the doctor $(\mathrm{b}=0.08 ; 95 \% \mathrm{CI}=0.04$ to 0.12 ; $\mathrm{p}<0.001)$, and accreditation of Puskesmas $(b=1.90 ; 95 \% \mathrm{CI}=1.60$ to 2.20 ; $\mathrm{p}<0.001)$. The effects of doctor's motivation and experiences were not statistically significant. Puskesmas had a substantial contextual effect on the quality of health service with intra-class correlation (ICC) $=34.31 \%$.
\end{abstract}

Conclusion: The quality of health service in Puskesmas increases with patient income, health insurance status, educational status, work satisfaction of the doctor, and accreditation of Puskesmas.

Keywords: contextual factor, motivation, work satisfaction, accreditation, quality of health service, Puskesmas

\section{Correspondence:}

Lukman Aryoseto. Masters Program in Public Health, Universitas Sebelas Maret, Jl. Ir Sutami 36A, Surakarta, Central Java. Email: lukmanaryoseto@gmail.com. Mobile: 081215930330. 